\title{
Discussions of the 1960-1970s on the Spatial and Economic Development of Siberia: Searching for a Balance between Heavy and Light Industries and Agriculture
}

\author{
Rinat Rezvanov* \\ Siberian Federal University \\ 79 Svobodny, Krasnoyarsk, 660041, Russia
}

Received 27.08.2018, received in revised form 26.10.2018, accepted 09.11.2018

The article concerns the main conceptual approaches in 1960-1970s towards the issue of spatial and economic (spatial and household) development of Siberia. The discourse analysis is focused on discrepancies in economic models among the representatives of leading Soviet research centers involved in "Siberian issue" investigation per se. They are especially the Council for the Study of Production Forces at the State Planning Committee of the USSR (CSPR, Moscow) and the Institute of Economics and Industrial Management at SB AS (IEIM, Novosibirsk). These also may include the Institute of Siberian and Far East Geography at SB $A S$ (ISFEG, Irkutsk), though the amount of its conceptual scientific and research findings was a way below the ones of CSPR and IEIM. The processes were mainly performed by the local authorities as well: a relevant example here is a study of the developing Achinsk-Nazarovo and Abakan-Minusinsk industrial hubs conducted by IEIM under the order of the Council of National Economy of Krasnoyarsk - an owner of the research and final decision-making center.

Keywords: Siberia, Soviet planning, Soviet industrialization in Siberia, spatial and economic planning, urban development, migration of population, women's issue, Krasnoyarsk Krai, Novosibirsk, Irkutsk Oblast', Altai Krai, Siberian cities, migration processes, history of Russia, history of USSR.

Research area: history.

Citation: Rezvanov, R. (2018). Discussion of the 1960-1970s on the spatial and economic development of Siberia: Searching for a balance between heavy and light industries and agriculture. J. Sib. Fed. Univ. Humanit. soc. sci., 11(11), 1896-1910. DOI: 10.17516/1997-1370-0346.

(c) Siberian Federal University. All rights reserved

* Corresponding author E-mail address: kraspgk@yandex.ru

This work is licensed under a Creative Commons Attribution-NonCommercial 4.0 International License (CC BY-NC 4.0). 


\section{Introduction}

The article has regard to methodological basis of the history of intellectual ideas with its detailed attention to the textual sources and corresponding interpretational (hermeneutic) structures, and to the context in the chronology of which the discourse of scientific intertextuality has been built (Repina, 2009: 7-80). It is increasingly important to identify polemical field in the original works of the Soviet analytic centers (CSPR, IEIM, ISFEG). Taking into consideration the creed of intellectual history stated by Alan Megill, an American historian: "the ideas have consequences, and this is the reason why they deserve critical and historical investigation" (Megill, 2005: 20), - for the modern Russian economy this factor is becoming remarkably significant, since the concepts considered in this research (conventionally: both of the State Planning and IEIM) have been implemented.

Industrial development of the East unavoidably encountered the problem of high capital intensity on running the projects. Every new project devolved into incomparably huge material and economic costs by the side of the Western districts. Siberian specific character impacted, as a rule, 1.5 appreciation of construction and installation works, and the building period was two or three times longer. All these were claimed by the Soviet researchers back to the beginning of the 1970s (Kotliar, 1989: 16).

In Siberia per se, regarding its territorial heterogeneity, trans-regional differentiation could show far bigger gap in the figures. For example, in Norilsk, in the center of the Northernmost development of the regional production complex in the Soviet Union, the cost of social services appeared to be 3.5 times higher, than in Krasnoyarsk (Vorobiyov, 1977: 128).

Thus, the state set its hopes on science for effective measures that would allow cutting costs. The economists were meant to plan and rationalize properly the economics of location; otherwise, the price for a mistake in implementation of the major complex projects (e.g., localization of regional production complexes) could have been prohibitively high.

Dealing with the problem of high costs, the Soviet economists paid their attention to the payroll budget. To the East of this country permanent payment costs were added with the necessity of wage indexation and introduction of complementary measures on material rewards. The indexation, "Northern allowances" in particular, was meant to act to attract and retain staff in the districts with unfavorable natural climatic conditions and undeveloped social, cultural and living infrastructure. An important milestone in the development of the system of public encouragement was the adoption 
of joint Decision of the CPSU Central Committee and the USSR Cabinet dated on February 4, 1960 "On Regulating the Benefits for People, Working in the Territories of Extreme North and Equated Areas". It introduced extra-10\% payment to the monthly wage (excluding the regional coefficient and employment year reward) depending on the territory and employment history.

The reality was that locally the increased salary rate was not often followed. According to the East Siberian Planning Committee, in the end of 1968 real earnings of the material sector employees in the Eastern Siberia was $94 \%$ and the ones of non-production sphere $-81 \%$ relatively to the Republic's average indicator (i.e. in the RSFSR). And these were the results on the background of higher costs, which, according to the Planning Committee, were bore by the residents of Irkutsk Oblast' in comparison with the central districts: "on heating - by $90 \%$, on clothes - by $18 \%$, while the market prices on Siberia are 30\% higher than in the European part of the country" (Araslanova, 2015: 20).

Nevertheless, the focus on material encouraging was among priorities. As early as in the 1980 the Far East was placed $1^{\text {st }}$ on the level of average monthly earnings, alongside with the Eastern and Western Siberia $-2^{\text {nd }}$ and $3^{\text {rd }}$ correspondingly (Breev, 1977: 47).

From the perspective of the scientists of the Council for the Study of Production Forces at the State Planning Committee of the USSR, it was the reduction of relative costs on salaries in the Eastern part of the country, in the Extreme Northern areas (and equated in particular), that could help to overcome the impact of negative production appreciation.

The State Planning of the USSR relied on three main parameters of the economic development in that territory:

1. Enhancement of sectoral economy through the spatial and production plans streamlining;

2. Implementation of "industrial triad" made up of comprehensive mechanization, automatization and electrification of production. It meant to use machines and mechanisms featured with "Siberian", "Northern" configuration (i.e. given low temperatures, permafrost, highly broken landscape and other unfavorable factors);

3. Labor force saving, both from technical and institutional perspectives (Kistanova, 1978: 49).

The management of costs cutting was dominated by the territorial-sectoral planning. Here too, the Soviet planning committees preferred the development of 
fuel and power and energy intensive industries, machine building enterprises and equipment production, as well as extracting and forest industries.

Having adopted the main lines, the Soviet economic planning was no longer considered underdevelopment of other, non-prior regional productions, to be a mistaken omission. According to the Central Institutions, they could have even become competitors for the systemic companies. It was attributable to the following: "one cannot classify slow in comparison with the Union's average level development of such labour-intensive sectors as precision engineering, chemical proceeding industry, light industry, etc. under economic disadvantages of labour-deficit territories. Enhancing growth of these productions given the labour deficit may well downward the pressure of other, more effective industries..." (Kistanova, 1978: 62).

"Comparatively slight growth of population and labour force ultimately insists on emphasizing the development of energy-intensive industries. In the Eastern Siberia it is relevant to produce aluminum, copper, nickel, ferrous-based alloys, chemical fibers, paper, etc. (Vorobiyov, 1977: 128). In two decades after the "Eastern" decisions had been adopted at the $20^{\text {th }}$ Communist Party Congress, the Soviet economists successively implemented the set of strategic productions.

There were no serious structural shifts in the spatial and economic planning, and the general industrial trend was determined by the same old factors. Hence was the focus on energy-intensive and resource-based industries - the first which were to be staffed. The words matched the deeds. Table 1 below clearly demonstrates how high the proportion of people employed in Siberian heavy industries was in 1960-1970s.

For us, 1.5-2 times lower number of persons employed in light industry in the Eastern Siberia in comparison with the all-Union average rate is also evident. At the same time, equal rates were maintained in the food industry, owing to the necessity to provide rapidly growing urban population with the most essential products. Besides, the residents of the areas with traditional use of nature (deer breeding, gathering, fishing, etc) were automatically classified as employed.

The policy of accelerated development of heavy industry increased the demand on men in work. There was a clear misbalance in the employment structure that was becoming more and more inflexible and unilateral - thus, the problem of comprehensive utilization of the labour force appeared.

On the cusp of 1950-60s the Institute of Economics and Industrial Management at SB AS (Novosibirsk) and the Council of National Economy of Krasnoyarsk conducted 
Table 1. Informal structure of employment by industry types in Siberia and the Far East (industrial and production staff, as $\%$ of total)

\begin{tabular}{|l|c|c|c|c|c|c|c|c|}
\hline \multirow{2}{*}{\multicolumn{1}{|c|}{ Industry }} & \multicolumn{4}{|c|}{1960} & \multicolumn{5}{c|}{1970} \\
\cline { 2 - 11 } & USSR & $\begin{array}{c}\text { Western } \\
\text { Siberia }\end{array}$ & $\begin{array}{c}\text { Eastern } \\
\text { Siberia }\end{array}$ & $\begin{array}{c}\text { Far } \\
\text { East }\end{array}$ & USSR & $\begin{array}{c}\text { Western } \\
\text { Siberia }\end{array}$ & $\begin{array}{c}\text { Eastern } \\
\text { Siberia }\end{array}$ & $\begin{array}{c}\text { Far } \\
\text { East }\end{array}$ \\
\hline Electrical energy & 2 & 2 & 3 & 3 & 2 & 2 & 3 & 3 \\
\hline Fuel & 7 & 14 & 6 & 8 & 5 & 10 & 5 & 6 \\
\hline Iron and steel industry & 5 & 5 & 1 & 1 & 4 & 4 & 1 & 1 \\
\hline Chemical and oil and gas & 3 & 4 & 3 & 1 & 4 & 6 & 3 & 1 \\
\hline Engineering and metal industry & 32 & 35 & 19 & 25 & 38 & 41 & 23 & 29 \\
\hline $\begin{array}{l}\text { Timber, woodworking, cellulose } \\
\text { and paper }\end{array}$ & 12 & 12 & 29 & 20 & 9 & 10 & 26 & 17 \\
\hline $\begin{array}{l}\text { Construction materials } \\
\text { (including glass industry) }\end{array}$ & 7 & 6 & 7 & 7 & 7 & 5 & 8 & 7 \\
\hline Light industry & 17 & 11 & 9 & 7 & 16 & 10 & 10 & 9 \\
\hline Food industry & 9 & 8 & 8 & 20 & 9 & 8 & 7 & 17 \\
\hline
\end{tabular}

Reference to: (Kistanova, 1978: 43).

a wide-scale socio-economic survey in the Achinsk-Nazarovo and Abakan-Minusinsk industrial hubs. The local authorities were recommended to reject the current practice of consumer goods delivered from the Western territories of this country. To achieve this goal they were asked to build their own textile, cabinet, garment, footwear, soap and other manufactures (Tsimdina, Sergievskaya, 1961: 70).

It obviously differed with a general approach, which not just lead the food industry to some distant corner, but also recognized and approved its slight development. In the end of 1970s this idea was more fully expressed by Nadezhda Kistanova, an economist of the Council for the Study of Production Forces at the State Planning Committee of the USSR. She assumed basing on the calculations made in her Department, which demonstrated that "delivery of a number of food products into the newly explored districts of the North and East even from the remote European districts in many cases provides (due to the difference in the price of agricultural raw materials) with higher national economy in comparison with the production of the same goods in the region per se" (Kistanova, 1978: 71).

A rigid focus on the development of strategic industries, albeit by the refusal of proper organization of light and food industries in the East, directly impacted the prospects for agriculture. While it was economically reasonable to deliver the food, Siberian settlement was meant to give its main resource - employees - to industrial cities in return. 
More vividly, the interest of the central planning committees towards implementation of highly economical and less labour-consuming productions in the East can be exemplified through the project of East-Siberian metallurgical plant which never took place. In 1930s it was meant to be built in the suburbs of Taishet (that time relatively small settlement inhabited with $10-12$ ths people; Taishet was recognized as "town" in 1938) in the west of Irkutsk Oblast'. The conferences of 1947 and 1948 conducted in this place proved the necessity to build the plant. Moreover, the 1948's conference suggested accelerating the process of construction, along with developing the Korshunovsk mining and processing works - the plant's raw material base.

The East-Siberian Plant was to become a fully integrated production (cast iron steal - rolled products) with an output of 7-8 mln tones of flat steel annually. The target high performance indicators were demonstrated by the fact that iron smelting per one BFS worker was meant to be 20 ths tones per year. That was despite 5-8 ths tones demonstrated by the leading productions in the USA. Yet, further, it was planned to switch to direct reduction of iron in steelmaking. Such contemporary production was invented in the Soviet Union just in the beginning of 1980s at the Staro-Oskol electrometallurgical works, yet with much lesser capacity $-1.5 \mathrm{mln}$ tones of steel annually (Sukhodolov, 2015: 7-8). This plan was not brought into effect. The Korshunovsk mining and processing works started providing the West-Siberian metallurgical works in Novokuznetsk (Kemerovo Oblast') constructed in 1964 with iron-ore concentrate. Still, the project's idea on creating an advanced production aimed at minimum workforce and high working efficiency turned out to be very demonstrative.

In 1960 the Institute of Economics and Industrial Management at SB AS (IEIM) initiated a comprehensive study of workforce utilization in Achinsk and Nazarovo districts of Krasnoyarsk Krai (Achinsk, Bogotol, Nazarovo, Uzhur and Bolshoi-Uluy districts). The field researches led to a system of proposals on workforce planning with changes in the location of production. These suggestions were characterized by their sustainability on the problem of enterprise organization planning that finally caused regular clashes between the colleagues from the Council for the Study of Production Forces at the Union's State Planning Committee and the Institute of Siberian and Far East Geography at SB AS of the USSR.

Being established in 1957 in Academgorodok (Academic Town), in Novosibirsk, IEIM was the first academic institute of economics east of the Urals. It significantly differed in methodological approaches from other specialized academic institutes. 
These approaches were mainly aimed at interdisciplinary: the citizens were quite ready to hold their researches at the intersection of economics, sociology, mathematics, statistics and geography. A great interest was paid to cybernetics, math modeling and software engineering which were enjoying popularity in the Soviet academic community. The strengths also included a remarkable body of practice, in the AchinskNazarovo and Abakan-Minusinsk production hubs.

The emphasis was upon the issues of rational location of regional production and efficient use of labour forces. The choice of just these two production hubs was predetermined by the plans of the Union's and regional authorities. The prospects of the Achinsk-Nazarovo production hub were linked to the fact that "this is the place where in 15-20 years ahead there will be a major industrial hub mainly dedicated to cheap coal form the Kansk-Achinsk lignite basin" (Tsimdina, Sergievskaya, 1961: 58). Shallow formations of coal beds allowed excavators to deliver the coal right into the rail cars: the extraction cost, thus, was equal to the loading coast. Taking into consideration such an important cost advantage, on June 5, 1955 the CPSU Central Committee and the USSR Cabinet adopted a joint decree "On construction of the Nazarovo State District Power Plant (SDPP)". The capital outlay there was four times less than the costs on the Saratov HPP (Nikiforov, 2010: 141). Such comparison is not a coincidence: the amount of building cost spent on the Saratov HPP was shot down in 1958 by Nikita Khrushchov and the construction was put on hold till 1964, and the workers were reassigned to build the Balakovo fiber material plant.

The Abakan-Minusinsk industrial hub was that time maintained by power sector (that had already been mentioned by the time of the Sayansk HPP establishment) forest, iron-ore and coal-mining industries, as well as extremely energy-intensive non-ferrous industry. In this way, "the overall assessment of the Abakan-Minusinsk hub's capacity was made during the conference productive forces development in the Eastern Siberia (Irkutsk, 1958 - author's note), which pointed out that this district (alongside with the areas of lower reaches of the Selenga in Buryatiya) was the most prosperous in the Eastern Siberia for a wide-scaled national economy development and advanced construction for the immediate future" (Zakharina, 1961: 74).

The research group of IEIM also mentioned a key economic and geographical feature of the local productive forces: high level of industrial concentration in the major cities mixed with its low development in adjacent areas. Both hubs, as it was stressed by the economists, were to be provided with regular labour and engineering staff "properly", i.e. with "high priority". 
The researchers formed a sequential socio-economic model of regional development. It can be clearly explained through the territories of Nazarovo and Chernogorsk, where the heavy industries (energetics and coal-mining) created a strong imbalance to male labour. On the back, this factor damaged the principle of comprehensive utilization of labour force and worsened the employment pattern misbalance. Eventually, the situation resulted in extremely high degree of labour turnover.

The practice showed that alone in 1959 in "Achinskaluminstroy" trust more than a half of employees were replaced. The same can be said about the construction of the Nazarovo HPRP, where the "turnover" of labour force was all in all assessed as $60 \%$. The total losses were pretty much remarkable: "if we consider, that an average break caused by relocation is 15 days (according to the study by Zh.A. Zaionchkovskaya in Achinsk and Nazarovo), so the lost working days per year in Achinsk and Nazarovo alone are more that 100 ths man-days" (Tsimdina, Sergievskaya, 1961: 64). These measures exemplify only two towns where as on 1959 the population was about 50 ths people (Achinsk) and 30 ths people (Nazarovo).

"Hyper-turnover" of labour forces on new constructions was pervasive for the whole Siberia. Thus, in 1961 the Bratsk HPS development was provided with 5385 workers by organizational recruitment, while 1247 quitted the work the same year, i.e. $24 \%$ of the amount of newcomers (Nikiforov, 2010: 143).

Such situation could not be tolerated by the local authorities, the Regional Council of National Economy in particular. Thus, there was an increased attention to the research group of IEIM. Dina Zakharina noted: “...one can see a great practical importance of the studies of labour force use. Even in the early stages, the findings were used by the local government. The attention towards the Abakan-Minusinsk hub has increased. Adjusting the seven-year plan, the Council of National Economy of Krasnoyarsk Krai outlined a number of new industrial objects, which previously had been planned in other places" (Zakharina, 1961: 83).

According to the scientists from IEIM, the difference could be made by housing. It was also necessary to improve the whole material working environment in the areas of new industrial construction. Elimination of that disbalance in the employment pattern could be achieved through the development of regional light and food industries which were mainly centered on female labour. That would also help to solve the problem of supplying the local population with their own made goods.

That time, the share of local light and food production in Siberia was relatively small, the biggest part of consumer goods was delivered from the western territories of 
this country, within 2-3 ths km or more. IEIM agreed on the fact which soon caused conceptual economic discussions: "at the time, such transportations were economically reasonable, but the growth of heavy industry and rapid increase in population were raising the issue of more extensive development of light and food industries in Siberia per se" (Tsimdina, Sergievskaya, 1961: 70). IEIM's attitude was balanced enough there was nothing said about blind spatial distribution of these industries, but about the degree of development of corresponding productions in the region and resource security.

The researchers assumed the natural scarcity for such development in the Achinsk and Nazarovo group of districts. Still, there was a wide range of productions, leaning towards the consumption areas, the layout of which was slightly dependent on transport distances. One, thus, did not concern the leftover principle in creating these productions after the industrial objects would be built, but simultaneous and parallel construction. "In order to involve female labour in social production, in Achinsk and Nazarovo in particular, it is necessary to foresee faster development rates for light and food industries, as well as for services... the growth rates of service industries should, to some extent, match the growth of population" (Voprosy trudovykh resursov..., 1961: 83).

By 1965, after the coal-mining extension and the launch of the Nazarovo Power Station's first line there was forecast on a sharp disbalance in the pattern of male/ female labour, in case there would be no stabilizing measures. It was quite reasonable to launch the following manufactures: textile, cabinet, clothing, footwear and soapmaking productions. Obviously, there was no question about the necessity to introduce all these factories, but they were considered as favorable to be located in the region.

The opinion of IEIM was heard by the Council of National Economy of Krasnoyarsk Krai and by the mid of 1960s Nazarovo met the cabinet and clothing factories, bread factory (was initiated back in 1961) and consumer service center. In the coal-mining Chernogorsk, strategically important center of the Abakan-Minusinsk industrial hub, two shops of the Zaozyorniy mica factory - one of the leading manufactures in the USSR - were built. In the end of 1950s the Council of National Economy agreed on recognizing these shops in Chernogorsk as separate independent factories. In 1960 the Chernogorsk worsted-cloth combine - the single largest in the region work was launched there. The project also included construction of two knitting factories (Voprosy trudovykh resursov..., 1961: 64).

The vision declared by IEIM differed from the arguments made by the followers of "weak", slow development of light industry in the East. The Council for the Study of 
Production Forces at the State Planning Committee of the USSR preferred using the ratio of key Siberian economic indicators. They included scaled up wages and demand for additional investments (caused, in turn, by more severe natural and climatic conditions), as well as supply with cheap fuel and energy resources. Relying on the assessment of each factor, CSPR admitted economic failure of textile production's location in the Eastern Siberia. Firstly, it created an overdemand for labour force that in the terms of labour deficit and necessity to save the labour compensation fund, was considered solely as a negative factor. Secondly, textile enterprises took relatively little amount of fuel and energy resources, large reserves of which were in Siberia that time. Much better option would be construction of a rayon staple factory in Siberia. In that case, a mere annual cost saving would exceed $1.5 \mathrm{mln}$ RUB in as to compared with the construction of similar production in the central part of Russia (Kistanova, 1978: 66-67).

The colleagues from the Institute of Siberian and Far East Geography at SB AS were even more critical: “...in underemployed areas it is unbeneficial to build textile productions (e.g. worsted-cloth combine), certain engineering factories (machinebuilding factories) even given the fact that their products are entirely devoted to consumption in the Eastern part of this country" (Vorobiyov, 1977: 128).

Presumably, the analysts in CSPR understood that female labour was a crucial backup for reproduction of that labour force in deficit. The general demographic

Table 2. Birth-rate indicators in the urban and countryside settlements in the RSFSR

\begin{tabular}{|c|c|c|}
\hline \multirow{2}{*}{ Year } & \multicolumn{2}{|c|}{ Number of births per 1000 persons in population } \\
\cline { 2 - 3 } & Urban settlements & Countryside settlements \\
\hline 1960 & 21,9 & 27,8 \\
\hline 1963 & 18,5 & 24,0 \\
\hline 1964 & 17,4 & 22,1 \\
\hline 1965 & 16,1 & 21,1 \\
\hline 1966 & 16,0 & 20,8 \\
\hline 1967 & 15,4 & 19,8 \\
\hline 1968 & 15,3 & 19,5 \\
\hline 1969 & 15,6 & 18,7 \\
\hline 1970 & 16,4 & 18,7 \\
\hline 1971 & 16,9 & 19,2 \\
\hline 1972 & 16,9 & 19,0 \\
\hline 1974 & 16,9 & 19,6 \\
\hline
\end{tabular}

Reference to: (Voprosy ekonomicheskogo rosta..., 1976: 68). 
trend of that time could not allow relying on remedying the situation and entering the employable age of millions of the Soviet people, able to fill the labour gap immediately. While in the 1950s the birth rate in the Soviet Union remained more or less stable, by the end of the 1950s and the beginning of the 1960s the country encountered the birth-rate falling (Table 2). The demographists explained such situation through the entering the childbearing age of the small-numbered "war" generation (Voprosy ekonomicheskogo rosta..., 1976: 66-67). Needless to say, that such demographic situation worsened the already tight balance of the labour force in the East. Since that time, the issue of female labour use obtained a new status in the Soviet studies of economics.

\section{Conclusion}

Summing up, we would like to identify a set of conclusions important for this research. The scientific methodological discussion on the problem of spatial and economic development of Siberia has been held by a number of Soviet research thinktanks, the most critical of which were the Council for the Study of Production Forces at the State Planning Committee of the USSR and the Institute of Economics and Industrial Management at SB AS. Having appeared at the boundary between 1950s and 1960, since IEIM at SB AS had been established, academic disputes have continued through the whole history of the Soviet Siberia. At the same time, one can notice both a common view which united IEIM and CSPR, and points of difference.

Thus, the alliance can be traced in the attitudes toward the productions preferred to be located in Siberia: energy-intensive, extracting (resource), with as small as possible amount of labour force (hence the concern about automatization and mechanization of “Siberian" industry). Still, the article's chronology is kept in the period of 1950-1960s for a good reason, since next decade is marked with a gradual switch of the Siberian industry towards science- and labour-driven upstream productions. In particular, an example is the projects on scientific and technological development of Krasnoyarsk Krai in during the second "ten-years advancement of Krasnoyarsk" (1981-1990s). According to the economic plans, two leading academic R\&D institutes in Krasnoyarsk - the current Institute of Chemistry and Chemical Engineering at SB AS (ICCE) and the R\&D Institution at the Krasnoyarsk Fuel-Power Complex under formation - were to arrange the second stage for the Kansk-Achinsk Fuel-Power Complex development. To achieve these goals by the year of 1988 ICCE shaped two main vectors - coalchemical and chemical-metallurgical ones which had by that time a well-developed profile with fundamental and applied solutions. And yet in 1989 in ICCE by the 
decision of the General Office of SB AS a super-institute was established there - the United Institute of Chemistry and Chemical Engineering at SB AS (consisting of the Institute of Chemistry and Chemical and Metallurgical Processes and the Institute of Natural Organic Raw Materials Chemistry) (Rubailo, 2012: 10). According to the plan after 1990 Krasnoyarsk Krai was to have energotechnological works for new fuels production, the scientific support of which was meant to enter the responsibility of the joint institute.

Differences in the attitudes to the spatial and economic planning in Siberia have been identified during active involvement of IEIM into the work of complex socioeconomic regional studies. The economists and sociologists and geographers from Novosibirsk made an in-depth investigation of the two major advanced regional industrial hubs: the Achinsk-Nazarovo and the Abakan-Minusinsk ones. Taking into consideration the importance of the context for the intellectual history, in this article, when considering the case, we have paid our attention to the preconditions for the R\&D expedition in the Krai (upon the request of the Council of National Economy of Krasnoyarsk, concerned about the high level of "labour turnover" at the hubs' objects) and main findings of the work conducted.

Namely basing on the results of IEIM's expedition in Krasnoyarsk, it is the first time when a necessity for not lower, a priori slow development of light and food industries, but notable fastened and keeping on the growth rate of prioritized industries was recognized as immediate recommendation. The attitude has further become "carte-de-visite" of the Novosibirsk economic and sociological school and successively realized in the process of interaction with the regional authorities in Siberia. Still, such position has met resistance of the Council for the Study of Production Forces at the State Planning Committee of the USSR, since by no means fitted the ideology of the spatial-industrial development of Siberia, mainly, due to its labour-intensive character.

\section{References}

Alekseev, V., Bukin, S., Dolgolyuk, A. et al. (1989). Industrial'noe osvoenie Sibiri: Opyt poslevoennykh pyatiletok. 1946-1960 gg. [Industrial reclaiming of Siberia: experience of the post-war five-year plans. 1946-1960]. Novosibirsk: Nauka. Sib. otd-nie.

Araslanova, V., Araslanova, A. (2015). Upravlenie trudovymi resursami v usloviyakh territorial'no-proizvodstvennykh kompleksov v SSSR (vtoraya polovina $\mathrm{XX}$ v.) [Labour force management in the context of spatial and production complexes 
in the USSR (the second half of the $20^{\text {th }}$ century)]. In Istoricheskaya $i$ sotsial'noobrazovatel'naya mysl' [Historical and Socio-Educational Ideas], 5-1, (7).

Breev, B. (1977). Podvizhnost' naseleniya i trudovykh resursov [Mobility of population and labour force]. Moscow: Mysl'.

Direktivy XX s'ezda KPSS po shestomu pyatiletnemu planu razvitiya narodnogo khozyaystva SSSR na 1956-1960 gody. [The guidelines on the $20^{\text {th }}$ Congress of the Communist Party of the Soviet Union on the $6^{\text {th }}$ five-year plan on development of national economy of the USSR in 1956-1960s]. In Dvadtsatyy s'ezd KPSS. Kommunisticheskaya partiya Sovetskogo Soyuza v rezolyutsiyakh $i$ resheniyakh s'ezdov, konferentsiy $i$ plenumov TSK (1898-1986). T. 9. 1956-1960. [The 20 ${ }^{\text {th }}$ Congress of the Communist Party of the Soviet Union. The Communist Party of the Soviet Union in resolutions and decisions made at congresses, conferences and plenary sessions of the Central Committee. Vol. 9: 1956-1960]. (1986). Moscow: Politizdat.

Kistanova, N. (1978). Regional'noe ispol'zovanie trudovykh resursov [Regional utilization of labour force]. Moscow: Nauka.

Kommunisticheskaya partiya Sovetskogo Soyuza v rezolyutsiyakh i resheniyakh s'ezdov, konferentsiy i plenumov TSK (1898-1986). T. 9: 1956-1960 [The Communist Party of the Soviet Union in resolutions and decisions made at congresses, conferences and plenary sessions of the Central Committee. Vol. 9: 1956-1960] (1986). Moscow: Politizdat.

Konferentsiya po izucheniyu proizvoditel'nykh sil Irkutskoy oblasti, 4-11 avg. 1947 g.: tez. dokl. [Proceedings of the conference on studying productive forces of Irkutsk Oblast', August 4-11, 1947]. Moscow, Leningrad: Izd-vo AN SSSR.

Kotliar, Z. (1989). Struktura zanyatosti naseleniya: problemy sovershenstvovaniya [Employment patter of population: problems of development]. Moscow, Nauka.

Megill, A. (2005). Globalizatsiya i istoriya idey [Globalization and the history of ideas]. In Dialog so vremenem [Dialogs with Time]. 14.

Nikiforov, V. (2010). Razvitie toplivno-energeticheskogo kompleksa Vostochnoy Sibiri v 50-80 gg. XX veka [The development of fuel and energetic complex in the Eastern Siberia in $50 \mathrm{~s}-80 \mathrm{~s}$ of the $20^{\text {th }}$ century]. In Uchyonye zapiski Rossiyskogo gosudarstvennogo sotsial'nogo universiteta [Proceedings of Russian State University of Sociology], 5.

Repina, L. (2009). Konteksty intellektual'noy istorii [The context of intellectual history]. In Dialog so vremenem [Dialogs with Time], 25 (1).

Rubailo, A., Pavlenko, N., Shor, A. (2012). Khimiya v Krasnoyarskom nauchnom tsentre: vchera, segodnya, zavtra [Chemistry in Krasnoyarsk research centre: yesterday, 
today and tomorrow]. In Radioelektronika. Nanosistemy. Informatsionnye tekhnologii [Radioelectronics. Nano-systems. Information Technologies], 4 (2).

Sukhodolov, A. (2015). Predposylki i perspektivy formirovaniya kompleksa chyornoy metallurgii v Vostochnoy Sibiri i Irkutskoy oblasti [The background and prospects in formation of iron industry complexes in the Eastern Siberia and Irkurtsk Oblast']. In Izvestiya Irkutskoy gosudarstvennoy ekonomicheskoy akademii [Bulletin of Irkutsk State Academy of Economics], 1 (25).

Tsimdina, Z., Sergievskaya, I. (1961). Opyt izucheniya ispol'zovaniya trudovykh resursov Achinsko-Nazarovskoy gruppy rayonov [The experience of studying of labour forces utilization in the Achinsk and Nazarovo group of districts]. In Voprosy trudovykh resursov v rayonakh Sibiri [Problems of labour forces in Siberian districts]. Novosibirsk.

Voprosy ekonomicheskogo rosta SSSR [Problems of economic growth in the USSR] (1976). Moscow: Izd-vo MGU.

Voprosy trudovykh resursov $v$ rayonakh Sibiri [Problems of labour force in Siberian districts] (1961). Novosibirsk.

Vorobiyov, V. (1977). Naselenie Vostochnoy Sibiri (sovremennaya dinamika $i$ voprosy prognozirovaniya) [Population of the Eastern Siberia (current dynamics and forecast issues)]. Novosibirsk: Nauka.

Zadorin, A. (2012). Poselencheskaya struktura Krasnoyarskogo kraya v kontse 50 - kontse 80-kh gg. XX v [Settlement pattern in Krasnoyarsk Krai in the end of 50s in the end of $80 \mathrm{~s}$ of the $20^{\text {th }}$ century]. In Vestnik Krasnoyarskogo gosudarstvennogo pedagogicheskogo universiteta im. V.P. Astaf'eva [Bulletin of Krasnoyarsk State Pedagogical University named after V.P. Astafiev], 1.

Zakharina, D. (1961). Ob ispol'zovanii trudovykh resursov Abakano-Minusinskogo uzla [On the problem of labour force utilization in the Abakan-Minusinsk hub]. In Voprosy trudovykh resursov $v$ rayonakh Sibiri [Problems of labour force in Siberian districts]. Novosibirsk.

Zanyatost' $v$ nebol'shikh gorodakh (Ekonomiko-geograficheskiy aspekt) [Employment in small towns (economico-geographical aspect)] (1978). Moscow: Statistika. 


\title{
Дискуссии 1960-1970-х годов \\ о пространственно-экономическом развитии Сибири: \\ в поисках баланса между тяжелой, легкой индустриями \\ и сельским хозяйством
}

Р. Резванов

Сибирский федеральный университет, Россия, 660041, Красноярск, пр. Свободныий, 79

\begin{abstract}
В статье анализируются основные кониептуальные подходы 1960-1970-х годов к проблематике пространственно-экономического (или территориально-хозяйственного) развития Сибири. Фокус дискурсивного анализа сосредоточен на расхождениях в экономических моделях представителей ключевых советских исследовательских центров, непосредственно занятых разработкой «сибирской проблематики». Речь идет, прежде всего, о Совете по изучению производительных сил при Госплане СССР (СОПС, Москва) и Институте экономики и организации промышленного производства СО АН СССР (ИЭОПП, Новосибирск). К ним можно отнести и Институт географии Сибири и Дальнего Востока СО АН СССР (ИГСиДВ, Иркутск), хотя объем его концептуальных научно-исследовательских разработок значительно уступал СОПСу и ИЭОПП. Ключевыми факторами прочессов являлись и региональные власти: важен пример с проведенным ИЭОПП по заказу Красноярского совнархоза исследованием формируюшихся Ачинско-Назаровского и Абакано-Минусинского промылиленных узлов. Совнархоз выступал и заказчиком научных работ, и центром принятия решений по их итогам.
\end{abstract}

Ключевые слова: Сибирь, планирование в советский период, индустриализация Сибири в советский период, пространственно-экономическое планирование, развитие городских поселений, миграция населения, проблема женщин, Красноярский край, Новосибирск, Иркутская область, Алтайский край, сибирские города, миграционные процессы, история России, история СССР.

Научная специальность: 07.00.00-исторические науки. 